\title{
Posterior annulus shortening increases leaflet coaptation in ischemic mitral incompetence: a new and valid technique
}

\author{
R Hetzer, A Amiri, N Solowjowa, H Siniawski, E Delmo Walter \\ From 23rd World Congress of the World Society of Cardio-Thoracic Surgeons \\ Split, Croatia. 12-15 September 2013
}

\section{Background}

We introduce a valid concept and strategy of a posterior annulus shortening to augment leaflet coaptation in ischemic mitral incompetence (IMI), and report its long-term outcome.

\section{Methods}

The technique consists of posterior annulus shortening reducing the annular diameter between 23 and $25 \mathrm{~mm}$ and decreasing its orifice to between 3.5 to $4.5 \mathrm{~cm} 2$. This size is sufficient to ensure an adequate leaflet coaptation area. The shortened annulus is reinforced by an untreated autologous pericardial strip. This augments the posterior leaflet by increasing the ratio of leaflet area/valve orifice where the gap in coaptation is the greatest. The area which the posterior leaflet offers to the anterior leaflet for coaptation during closure is heightened by the tissue strip, making valve closure possible even in advanced leaflet restriction.

\section{Results}

Between 1992 and 2012, 75 patients (mean age $64.56 \pm$ 10.37, range 35.0-86.1, years) underwent posterior annulus shortening to augment leaflet coaptation surface area in repair of IMI. At a mean follow-up of $7.62 \pm 0.66$ (range 3.6-20.9) years, NYHA functional class significantly improved, LVEFF increased and there was a tremendous abatement of MI $(\mathrm{p}<0.01)$. Annular area was reduced from $9.2 \mathrm{~cm} 2$ to $5.8 \mathrm{~cm} 2$. From a complete absence of coaptation area, it creased to $6.6 \mathrm{~mm}$ after the repair. CT showed posterior annulus size reduction from $70.4 \mathrm{~mm}$ to $64 \mathrm{~mm}$ and an increase in posterior leaflet length from

\footnotetext{
* Correspondence: delmo-walter@dhzb.de

Cardiothoracic Surgery, Deutsches Herzzentrum Berlin, Berlin, Germany
}

15.92 to $19.6 \mathrm{~mm}$. A most remarkable CT finding was the increase in coaptation length from 5.2 to $8.2 \mathrm{~mm}$. Freedom from reoperations were $95.3 \pm 2.7 \%$ and $86.4 \pm 5.6 \%$, and survival rates were $71.9 \pm 5.5 \%$, and $65.1 \pm 6.3 \%$ at 1 and 18 years, respectively. Freedom from moderate or greater $\mathrm{MI}$ is $80.7 \pm 9 \%$ at 10 years.

\section{Conclusion}

Posterior shortening annuloplasty with pericardial strip augmentation addressing the lack of leaflet coaptation, is a simple and highly effective repair technique to restore valve competence in ischemic MI.

Published: 11 September 2013

doi:10.1186/1749-8090-8-S1-0276

Cite this article as: Hetzer et al.: Posterior annulus shortening increases

leaflet coaptation in ischemic mitral incompetence: a new and valid technique. Journal of Cardiothoracic Surgery 2013 8(Suppl 1):O276.

Submit your next manuscript to BioMed Central and take full advantage of:

- Convenient online submission

- Thorough peer review

- No space constraints or color figure charges

- Immediate publication on acceptance

- Inclusion in PubMed, CAS, Scopus and Google Scholar

- Research which is freely available for redistribution

Submit your manuscript at www.biomedcentral.com/submit 